\title{
Polysaccharides of St. John's Wort Herb Stimulate NHDF Proliferation and NEHK Differentiation via Influence on Extracellular Structures and Signal Pathways
}

\author{
S. Abakuks and A. M. Deters \\ Institute for Pharmaceutical Biology and Phytochemistry, Westphalian Wilhelms University of Münster, Hittorfstra Be 56, \\ 48149 Münster, Germany \\ Correspondence should be addressed to A. M. Deters, adeters@uni-muenster.de
}

Received 3 February 2012; Revised 13 April 2012; Accepted 13 April 2012

Academic Editor: Abdelwahab Omri

Copyright () 2012 S. Abakuks and A. M. Deters. This is an open access article distributed under the Creative Commons Attribution License, which permits unrestricted use, distribution, and reproduction in any medium, provided the original work is properly cited.

\begin{abstract}
St. John's Wort herb extracts often contain undesirable or volitional polysaccharides. As polysaccharides exhibit structuredependent biological functions in the present study water-soluble polysaccharides were extracted from herb material, fractionated by anion exchange chromatography into four main polysaccharide fractions (denominated as Hp1, Hp2, Hp3 and Hp4) and characterized by HPAEC-PAD, CE, IR and GC-MS. Biological activity on human skin keratinocytes and fibroblasts was assessed by investigation of their effect on proliferation, metabolism, cytotoxicity, apoptosis and differentiation. The underlying mechanisms were investigated in gene expression studies. Polysaccharide fraction $\mathrm{Hp} 1$ was mainly composed of $\beta$-D-glucose. Hp2, Hp3 and $\mathrm{Hp} 4$ contained pectic structures and arabinogalactan proteins varying in composition and quantity. Polysaccharides of Hp1 induced the keratinocyte differentiation by inhibiting the gene expression of the epidermal growth factor and insulin receptor. While the collagen secretion of fibroblasts was stimulated by each polysaccharide fraction only Hpl stimulated the synthesis. The fibroblast proliferation was reduced by $\mathrm{Hp} 1$ and increased by $\mathrm{Hp} 4$. This effect was related to the influence on genes that referred to oxidative stress, metabolism, transcription processes and extracellular proteins. In conclusion polysaccharides have been shown as biologically active ingredients of aqueous St. John's Wort extracts with a relation between their structural characteristics and function.
\end{abstract}

\section{Introduction}

Extracts of St. John's Wort (Hypericum perforatum L., Hypericaceae) are well investigated and widely used in regard to their effectiveness against moderate depressions. The responsible naphthodianthrones, phloroglucinol derivates, and flavonoids were extensively investigated [1]. Concerning biological activity on the skin the investigations focused on the phototoxicity of lipophilic and aqueous-ethanolic extracts for many years. Beside the ongoing discussion concerning the phototoxicity of St. John's Wort extracts [2, $3]$, it has been reported that hyperforin induced keratinocyte differentiation in vitro and the skin hydration in vivo $[4,5]$. Nevertheless more information is needed concerning the less investigated side products of extraction. Especially the carbohydrates that conflict with formulation, development, and production of solid dosage forms [6] were mostly seen as nonactive byproducts. There are some reasons for investigation of St. John's Wort polysaccharides. First of all no information is available concerning composition and structure of polysaccharides in Hypericum species and cognate plants. Again aqueous-ethanolic extracts of St. John's Wort possess high viscosity indicating coextraction of plant polysaccharides. According to their structural characteristics, herbal polysaccharides are able to influence the immunologic response [7], bacterial adhesion [8], and tumor inhibition [9]. Furthermore they promote the tissue regeneration [10], protect against tissue injury [11], or reduce skin aging [12]. With respect to the multifunctional bioactivities of polysaccharides, it is likely that the effect of St. John's Wort extracts is not only related to the main components. As the bioactivity of polysaccharides is closely related to their 
composition, water-soluble polysaccharides of St John's Wort were fractionized according to their acidity and analyzed concerning composition and linkage prior to the investigation of their activity on skin cells. Normal human dermal fibroblasts (NHDF), HaCaT, and normal human epidermal keratinocytes (NHEK) are useful tools to investigate different aspects of cell physiology in in vitro studies and allow the examination of underlying mechanisms. The investigations of the present study focused on the proliferation (BrdUincorporation), the reductive enzyme activity (MTT and WST-1), involucrin and collagen expression and necrotic (extracellular lactate dehydrogenase activity) and apoptotic (Annexin V) effects of human skin cells. Mechanistical studies were carried out using real-time PCR and gene microarrays. As representative factors for RT-PCR, the fibroblast growth factor 7 (FGF-7), epidermal growth factor receptor (EGFR), insulin receptor, and the signal transducer and activator of transcription 6 (STAT6) were chosen as representative for proliferation related processes [13]. Regulation of differentiation on the gene level was assessed by phospholipase $\alpha$ (PLA2) [14] and involucrin [15]. An overlook over the affected signal pathways was obtained by gene microarray analysis of 1308 genes that refer to human skin.

\section{Materials and Methods}

2.1. Isolation and Characterization of Polysaccharides. $250 \mathrm{~g}$ of powdered St. John's Wort herb from Caesar and Loretz $\mathrm{GmbH}$, Bonn, Germany, was exhaustively extracted for $24 \mathrm{~h}$ in a Soxhlet extractor with acetone and methanol. The drug was identified by microscopic characterization, and a voucher specimen is deposited in the archive of the Institute for Pharmaceutical Biology and Phytochemistry (no. HP561/D). The residue was dried at room temperature and extracted 3 times each with $2 \mathrm{~L}$ Aqua Millipore under permanent stirring. The combined water extracts were concentrated using a rotary evaporator at $35^{\circ} \mathrm{C}$ and precipitated with ethanol $96 \%(\mathrm{~V} / \mathrm{V})$ to a final concentration of $80 \%$. The entire precipitated polysaccharides (RPSs) were isolated by centrifugation at $3600 \mathrm{xg}$, dialyzed against Aqua Millipore using cellulose membranes (MWCO $3.5 \mathrm{kDa}$ ) for 5 days at $4^{\circ} \mathrm{C}$, and lyophilized. Fractionation of RPS was performed according to the polysaccharides acidity by anion exchange chromatography on DEAE-Sephadex. Stepwise elution of polysaccharides was done with water and sodium phosphate buffers of increasing ionic strength (NaPB) according to Deters et al., 2005 [16]. For determination of the total carbohydrate, uronic acid and protein amounts polysaccharides were hydrolyzed with trifluoroacetic acid $2 \mathrm{~mol} / \mathrm{L}$ at $121^{\circ} \mathrm{C}$ for $60 \mathrm{~min}$ and analyzed by TLC on silica gel $\mathrm{F}_{254}$ glass plates using acetonitrile-water $80: 20(\mathrm{~V} / \mathrm{V})$ as a mobile phase. After threefold development the monosaccharides were detected using 2-isopropyl-5-methylphenol/sulphuric acid spray reagent and heating at $120^{\circ} \mathrm{C}$ for $5 \mathrm{~min}$. Reference standards for detection of neutral carbohydrates [17] and uronic acids [18] were prepared according to the monosaccharide and uronic acid composition determined via TLC. The protein contents were determined against reference concentrations of BSA (PAA, Laboratories, Coelbe) with Coomassie brilliant blue G250 [19]. Each of these tests was modified for use in 96-well-microtiter plates. A radial gel diffusion experiment using $\beta$-D-glucosyl-Yariv reagent [20] against gum arabic as reference $(0.25 \mathrm{mg} / \mathrm{mL}$, $0.5 \mathrm{mg} / \mathrm{mL}, 1 \mathrm{mg} / \mathrm{mL}, 2.5 \mathrm{mg} / \mathrm{mL}, 5 \mathrm{mg} / \mathrm{mL}, 10 \mathrm{mg} / \mathrm{mL}$ ) was used to test the polysaccharide fractions for the occurrence of arabinogalactan proteins (AGP). Starch was assayed using Lugol's solution.

2.2. Linkage Analysis of Polysaccharides. Uronic acid was identified by ion-exchange HPLC with pulsed-amperometric detection (Bio-LC, Dionex, Idstein, Germany) with an AS50 autosampler, GS50 gradient pump, AS50 oven, and ED50 electrochemical detector on a CarboPacTM PA1 analytical column, $2 \mathrm{~mm} \times 250 \mathrm{~mm}$, CarboPacTM PA1, guard column $2 \mathrm{~mm} \times 50 \mathrm{~mm}$, and BorateTrapTM, $4 \mathrm{~mm} \times$ $50 \mathrm{~mm}$ using a ternary gradient of water, $0.1 \mathrm{mM}$ sodium hydroxide, and $0.5 \mathrm{mM}$ sodium acetate. Neutral sugars were quantified by preparing trimethylsilyl derivatives: $10 \mathrm{mg}$ of hydrolyzed polysaccharide was mixed with $1 \mathrm{~mL}$ TriSil-Z (Pierce, Bonn, Germany) and heated for two hours at $80^{\circ} \mathrm{C}$. The separation and detection were done on a AGILENT Technologies 6890 system using an HP-PAS 1701 column $(0.32 \mu \mathrm{m} \times 25 \mathrm{~m} \times 0.25 \mu \mathrm{m})$ with helium as carrier gas and a temperature program from $160^{\circ} \mathrm{C}$ to $220^{\circ} \mathrm{C}$ with a heatingup rate of $10^{\circ} \mathrm{C} / \mathrm{min}$ (injector: $275^{\circ} \mathrm{C}$ ). Detection took place with a mass selective detector $(70 \mathrm{eV}$ ionization energy; $8 \mathrm{kV}$ acceleration voltage), AGILENT Technologies, Santa Clara, USA). Structures of polysaccharides were analyzed according to the permethylation method of $[21,22]$, and the reduction of uronic acids with sodium borodeuteride was performed as described by [23]. Permethylated alditol acetates were injected at $220^{\circ} \mathrm{C}$, gas chromatographed with a AGILENT Technologies $6890 \mathrm{~N}$ system on an HP-5MS column $(0.25 \mathrm{~mm} \times 30 \mathrm{~m} \times 0.25 \mu \mathrm{m})$ with helium as carrier gas and a temperature program from $170^{\circ} \mathrm{C}$ to $220^{\circ} \mathrm{C}$ with a temperature slope of $1^{\circ} \mathrm{C} / \mathrm{min}$. Mass fragments were detected with a mass selective detector (AGILENT Technologies, Santa Clara, USA) using $70 \mathrm{eV}$ ionization energy and $8 \mathrm{kV}$ acceleration voltage. The configuration of monosaccharides was determined by capillary electrophoresis versus D and $\mathrm{L}$ references using a P/ACE 5010 Instrument (Beckman Coulter, Krefeld, Germany) with an uncoated silica capillary $(77 \mathrm{~cm} \times 50 \mu \mathrm{m})$ and DAD UV detector at $200 \mathrm{~nm}$ according to the method of Noe and Freissmuth, 1995 [24]. Polysaccharides were investigated in regard to esterification with IRspectroscopy (mid-infrared) on a FT/IR-4100 type A (Jasco, Tokio, Japan) and a pectin C, which contained 70\% ester bounds as reference.

2.3. Cell Culture. Confined cell lines were obtained after isolation of normal human dermal fibroblasts (NHDFs) and normal human epidermal keratinocytes (NHEKs) from human skin grafts (University Clinical Centre of Münster, Germany, Department of Dermatology, Department of Pediatrics) of various Caucasian subjects. The studies were approved by the local ethical committee of the University of Münster (acceptance no. 2006-117-f-S). Subculture of cells 
was done as described earlier [16, 25]. HaCaT keratinocytes, a friendly gift of Professor Fusenig, DKFZ, Heidelberg, were used for apoptosis-related experiments.

2.4. Cell Viability, Proliferation, and Differentiation. For investigation, polysaccharides were solved in Aqua Millipore to a concentration of $1 \mathrm{mg} / \mathrm{mL}$, sterile filtered through a $0.2 \mu \mathrm{m}$ regenerated cellulose acetate membrane, and solved in the recommended serum-free media to a final concentration of $10 \mu \mathrm{g} / \mathrm{mL}$. As positive control, 10\% FCS was added to test medium. All tests were realized in 96-well plates (Sarstedt, Nuembrecht, Germany) at starting cell densities of $5 \times 10^{3}$ NHEK and $3 \times 10^{3}$ NHDF in each well. Incubation with polysaccharides started $24 \mathrm{~h}$ after seeding when the cells had reached a confluence of $50 \%$ and ended $48 \mathrm{~h}$ later by adding BrdU and WST-1 reagents. BrdU incorporation assay and WST-1 and LDH assays were performed according to the manufacturer instructions (Roche Diagnostics, Penzberg, Germany). Activity of intracellular reducing enzymes was measured with MTT [26]. Apoptosis was measured after incubation of NHDF and NHEK with $10 \mu \mathrm{g} / \mathrm{mL}$ polysaccharide by treating with Annexin V-PE and counterstaining with 7-aminoactinomycin (7-AAD) on a FACSCalibur flow cytometer (Becton Dickinson GmbH, Heidelberg, Germany). Cells were harvested by scraping in ice-cold Annexin V binding buffer, further proceeding following manufacture description. Differentiation of NHEK was elucidated by semiquantitative determination of involucrin amounts using the dot blot technique as described earlier [25].

2.5. Protein Expression of Cells. The collagen expression of fibroblasts was analyzed by a colorimetric method based upon Sirius Red. Therefore, NHDFs were seeded in 24-well cell culture plates (Greiner, Frickenhausen, Germany) with $7 \times 10^{4}$ cells/well. At $70 \%$ confluence the cells were incubated with $10 \mu \mathrm{g} / \mathrm{mL}$ polysaccharides solved in test medium, $100 \mathrm{mM} \mathrm{L}$-ascorbic acid was used as positive control [27]. After $48 \mathrm{~h}$, the culture supernatant $(0.5 \mathrm{~mL})$ was transferred to an Eppendorf cup and mixed with protease inhibitor mix (Roche Diagnostics, Penzberg, Germany). NHDFs were lysed by a fivefold freeze-thaw-cycle in $200 \mu \mathrm{L} 0.5 \mathrm{M}$ acetic acid containing protease inhibitor mix and scraped from the plate. The resulting cell suspension was conveyed in a new Eppendorf cup. Solutions of cells and culture supernatants were stirred overnight at $4^{\circ} \mathrm{C}$ and afterwards centrifuged for $10 \mathrm{~min}$ at $14,000 \mathrm{xg}$ to remove the cell debris. $50 \mu \mathrm{L}$ of the resulting solution was mixed with $450 \mu \mathrm{L}$ Sirius Red $(69 \mu \mathrm{g} / \mathrm{mL}, 0.5 \mathrm{M}$ acetic acid), agitated for $30 \mathrm{~min}$, and again centrifuged $(10 \mathrm{~min}, 14000 \mathrm{xg}$ ). Subsequently, the resulting pellet was solved in $50 \mu \mathrm{L} 0.1 \mathrm{M}$ potassium hydroxide, and the intensity of color was determined at $540 \mathrm{~nm}$ with a reference wavelength of $690 \mathrm{~nm}$.

2.6. Gene Expression Analysis of Keratinocytes and Fibroblasts by Real-Time PCR. Analysis of cellular signal transduction effected by St. John's Wort polysaccharides was done by gene expression analysis with real-time PCR after reverse transcription of total RNA. To exclude effects of FCS the fibroblasts were adapted to minimal MEM containing glucose $(4.5 \mathrm{~g} / \mathrm{L})$ and L-glutamine $(1 \%)$ but no other supplements for $12 \mathrm{~h} .10 \mu \mathrm{g} / \mathrm{mL}$ polysaccharides and 10\% FCS as positive control were solved in the minimal MEM prior to the incubation with NHDF for $6 \mathrm{~h}, 12 \mathrm{~h}$, and $24 \mathrm{~h}$. For untreated control cells fresh minimal MEM was used. After trypsinization of cells, the total RNA was isolated with the innuPREP RNA Mini Kit (Analytik Jena, Jena, Germany). After qualitative and quantitative analysis of obtained RNA with the biophotometer (Eppendorf, Hamburg, Germany) it was reverse-transcribed using the High-Capacity cDNA Reverse Transcription Kit. cDNA was diluted with RNAsefree water to $20 \mathrm{ng}$ cDNA, and real-time-PCR was performed with TaqMan gene expression assays (Table 1) and the TaqMan Universal MasterMix, without AmpErase on a 7300 Real Time PCR System (all Applied Biosystems, Foster City, USA). The gene expression was calculated with the comparative Ct method.

2.7. Microarray Analysis of Gene Expression. For gene microarray analysis, NHDFs were seeded at a cell density of $5 \times 10^{5}$ cells $/ 75 \mathrm{~cm}^{2}$ cell culture flask (Sarstedt, Nuembrecht, Germany). At a confluence of $70 \%$ the medium was changed against minimal MEM, containing $4.5 \mathrm{~g} / \mathrm{L}$ glucose as well as $1 \% \mathrm{~L}$-glutamine and kept for $12 \mathrm{~h}$ to adapt cells to minimal culture conditions. For $24 \mathrm{~h}$ the cells were incubated with polysaccharides, solved in minimal MEM $(10 \mu \mathrm{g} / \mathrm{mL})$, or only with fresh minimal MEM (control sample). After trypsinization the cells were washed with PBS and frozen in liquid nitrogen. Isolation and amplification of the RNA as well as the analysis of the gene expression via PIQOR Skin Microarray was performed by Miltenyi Biotech, BergischGladbach, Germany. For quality control the RNA integrity number (RIN) was determined with 8.2 (must be $>6$ ), indicating sufficient quality for gene expression experiments.

2.8. Statistical Analysis. Statistical evaluation was performed by Dunnett's post hoc test for comparison of three to four treatment groups after variance calculation by Levene. The results of three independent biological repeats were considered significant when the $P$ value was less than 0.05 . All data presented are the means of 24 random samples (errors bars: \pm SE) or representative with $n=8$.

\section{Results}

3.1. Isolation and Characterization of St. John's Wort Herb Polysaccharides. Carbohydrates were isolated from defatted St. John's Wort herb in a yield of $1.3 \%$ related to the starting material. The ochre brown product was assessed to be a polysaccharide with neutral sugar content of $78 \%$, $16 \%$ of uronic acids, and a residual protein content of $6 \%$. According to the ionic strength of the respective elution buffer and the acidity of polysaccharides, the AEC resulted in four polysaccharide fractions further referred to as $\mathrm{Hp} 1$, $\mathrm{Hp} 2$, Hp3, and Hp4. Main amounts of polysaccharides were eluted using $0.25 \mathrm{M} \mathrm{NaPB}(\mathrm{Hp} 3,47 \%)$. High acidic (0.5 M NaPB; Hp4) and low acidic polysaccharides $(0.1 \mathrm{M}$ $\mathrm{NaPB}$; Hp2) reached values of almost $23 \%$ each. $7 \%$ of 
Table 1: TaqMan Assay IDs (Applied Biosystems, Foster City, USA) of specific proteins and representatives of signal pathways expressed in normal human fibroblasts (NHDFs) and normal human keratinocytes (NHEKs) investigated by real-time PCR after treatment with $10 \mu \mathrm{g} / \mathrm{mL}$ St. John's Wort herb polysaccharide fractions.

\begin{tabular}{lll}
\hline Gene & Function & TaqMan Assay ID \\
\hline Epidermal growth factor receptor (EGFR) & Proliferation & Hs01076068m1 \\
Fibroblast growth factor 7 (FGF7) & Proliferation & Hs00384281_m1 \\
Insulin receptor (InsR) & Survival/proliferation & Hs00169631m1 \\
Involucrin (Inv) & Differentiation-specific protein & Hs00846307s1 \\
Signal transducer and activator of transcription 6 (STAT6) & IL-4 signal transduction & Hs00598618_m1 \\
Phospholipase $\alpha$ (PLA2) & $\mathrm{Ca}^{2+}$ signaling & Hs00179898_m1 \\
Human 18s rRNA (18s) & Endogenous control & Hs99999901s1 \\
\hline
\end{tabular}

polysaccharides were received by water elution ( $\mathrm{Hp} 1)$. The proportion of neutral sugars in the particular AEC fractions was determined as 93\% ( $\mathrm{Hp} 1), 69 \%(\mathrm{Hp} 2), 63 \%(\mathrm{Hp} 3)$, and 47\% (Hp4). By HPEAC-PAD uronic acids were identified and quantified as galacturonic acid and glucuronic acid. Protein analysis revealed protein amounts of 4\% (Hp1), $6 \%(\mathrm{Hp} 2)$, 5\% ( $\mathrm{Hp} 3)$, and 8\% ( $\mathrm{Hp} 4)$. The reaction with Yarif-reagent showed that the protein amounts originate from arabinogalactan proteins (AGP) in fractions $\mathrm{Hp} 2$ (75\%), Hp3 (3\%), and $\mathrm{Hp} 4$ (3\%) but not in fraction Hp1. Structural analysis was done after derivatization of hydrolyzed polysaccharides to silylated (TMS) derivates and permethylated alditol acetates (PMAA) followed by gas chromatographic separation and mass spectrometric detection. TMS derivatives were identified as arabinose, galactose, and glucose as well as rhamnose, xylose and mannose. Arabinose and galactose were present in a ratio of $1: 1$ in all fractions being the main monosaccharides in AGP containing fractions whereas $\mathrm{Hp} 1$ mainly contained glucose. Rhamnose was only present in amounts more than $10 \%$ in Hp2 and Hp4. Xylose and mannose were detected in minor amounts. In all fractions arabinose was found as terminal, $(1 \rightarrow 5)$, and 1,3,5 linked. The acidic fractions $\mathrm{Hp} 2, \mathrm{Hp} 3$, and Hp4 contained rhamnose linked in terminal, $(1 \rightarrow 2)$, and 1,2,3-linked forms. Xylose was linked in $(1 \rightarrow$ 2) position and terminal in $\mathrm{Hp} 1$. All fractions contained $(1 \rightarrow 4)$-linked mannose and $(1 \rightarrow 4)$-linked glucose but the test for starch was negative. Especially in $\mathrm{Hp} 1$ glucose was also linked in positions $(1 \rightarrow 6)$, terminal, $(1 \rightarrow 2)$, and $1,4,6$. $(1 \rightarrow 3)-,(1 \rightarrow 6)-$, and 1,3,6-linked galactose was detected in all fractions as well as $(1 \rightarrow 4)$ linked glucuronic acid. Galacturonic acid was found as $(1 \rightarrow 3),(3 \rightarrow 6)$, or $1,4,6$ linked (Table 2). Capillary electrophoresis revealed an Lconfiguration of arabinose and D-configuration of xylose, galactose, and glucose. Infrared spectrometry revealed that the galacturonic containing fractions exhibited absorptions at wavenumbers $1233 \mathrm{~cm}^{-1}$ and $1733 \mathrm{~cm}^{-1}$ in consequence of a partial esterification of the galacturonic acid residues.

3.2. Influence of St. John's Wort Herb Polysaccharides on Cell Physiology of Human Keratinocytes. The proliferation of NHEK was marginally influenced by each polysaccharide fraction with less than $20 \%$. Contrary to the polysaccharides of fractions $\mathrm{Hp} 1, \mathrm{Hp} 2$, and $\mathrm{Hp} 4$, the polysaccharides of $\mathrm{Hp} 3$ reduced the proliferation rates. MTT test revealed a slight but not significant increase of intracellular reducing enzymes activity after treatment of NHEK with all polysaccharide fractions. Necrotic effects of St. John's Wort herb polysaccharides were not observed on keratinocytes. Just weak apoptotic effects were observed with exception of HaCaT keratinocytes that were incubated with polysaccharides of fraction $\mathrm{Hp} 3$ (Table 3) whereas this effect was not significant.

After prolonged incubation time, NHEKs showed morphological changes in consequence of an incipient differentiation. For that after nine days the cellular proteins were extracted followed by a semi-quantitative determination of the differentiation-specific protein involucrin using dot blot technique.

As shown in Figure 1 the involucrin expression was significantly enhanced by polysaccharides of $\mathrm{Hpl}$ whereas the other polysaccharide fractions had no significant influence.

The large variations resulted from the different behavior of normal cells due to their diverse sources. First investigation of gene expression of differentiation-specific proteins and proliferation-related pathways indicated that after short incubation time of $6 \mathrm{~h}$ the involucrin gene expression is not altered independent of the used polysaccharide fraction for treatment. But in case of Hp1, which showed the most impact on the differentiation, the gene expression of proliferationrelated genes like EGFR and InsR was inhibited. The decrease in PLA2 expression that is part of the $\mathrm{Ca}^{2+}$ signaling and for that involved in the differentiation process revealed that the differentiation of NHEK is induced in a different way (Table 4).

3.3. Reactivity of Normal Human Dermal Fibroblasts to Polysaccharides of St. John's Wort Herb. Polysaccharide fractions of St. John's Wort herb did not influence the activity of reducing enzymes in the cells as measured by MTT reduction assay. But as shown in Figure 2 the extracellular enzymes of Hp1-, Hp3-, and Hp4-treated NHDF reduced significantly more WST-1 than the untreated cells. The proliferation of NHDF was significantly stimulated by polysaccharide fraction $\mathrm{Hp} 4$ and reduced by high glucose amount containing fraction $\mathrm{Hp} 1$. Fractions $\mathrm{Hp} 2$, and $\mathrm{Hp} 3$ had no influence on the proliferation. Cytotoxic activity was not observed. Even the amount of necrotic cells was reduced compared to the untreated cells $(0 \%):-2 \%$ in case of $\mathrm{Hp} 2, \mathrm{Hp} 3$ and $\mathrm{Hp} 4$ 
TABLe 2: Results of methylation analysis and AGP determination of St. John's Wort polysaccharides. Data indicate the respective molar composition [\%], calculated from results of HPAEC-PAD and silylation analysis. AGP amounts were detected by the agar diffusion test according to van Holst and Clarke, 1985 [20].

\begin{tabular}{|c|c|c|c|c|}
\hline & $\mathrm{Hp} 1$ & $\mathrm{Hp} 2$ & $\mathrm{Hp} 3$ & $\mathrm{Hp} 4$ \\
\hline 1-Ara & 6 & 23 & 6 & 1 \\
\hline 1,2-Ara & & 1 & & 1 \\
\hline 1,3-Ara & 3 & & 2 & \\
\hline 1,5-Ara & 6 & 5 & 12 & 10 \\
\hline 1,3,5-Ara & 2 & 3 & 1 & 2 \\
\hline 1,2,3-Ara & & & 2 & 3 \\
\hline 1,2,5-Ara & 2 & & 1 & 7 \\
\hline 1,3,4,5-Ara & & & 1 & \\
\hline Arapent & & & 1 & \\
\hline 1-Rha & & 1 & 3 & 4 \\
\hline 1,2 Rha & & 1 & 2 & 2 \\
\hline 3,4/1,4-Rha & & 9 & & 2 \\
\hline 1,2,3-Rha & & 1 & 2 & 6 \\
\hline $1-\mathrm{Xyl}$ & 1 & & & \\
\hline 1,2-Xyl & 1 & 1 & & 1 \\
\hline 1,3,5-Xyl & & & 1 & \\
\hline 1-Man & & & & 1 \\
\hline 1,4-Man & 2 & 2 & 3 & 3 \\
\hline 1,4,6-Man & 1 & & 1 & \\
\hline 1-Glc & 7 & & & 1 \\
\hline 1,3-Glc & 5 & & & 2 \\
\hline 1,4-Glc & 11 & 1 & 1 & 3 \\
\hline 1,6-Glc & 26 & & 2 & 1 \\
\hline 1,2,4-Glc & 2 & & & \\
\hline 1,4,6-Glc & 3 & & & 1 \\
\hline 1-Gal & 1 & 1 & 1 & \\
\hline 1,3-Gal & 2 & 1 & 3 & 3 \\
\hline 1,6-Gal & 5 & 5 & 5 & 3 \\
\hline 3,6-Gal & 1 & & 1 & 1 \\
\hline $1,2,4-\mathrm{Gal}$ & & & 1 & 1 \\
\hline $1,4,6-\mathrm{Gal}$ & 3 & 2 & & 1 \\
\hline $1,3,6-\mathrm{Gal}$ & 6 & 23 & 21 & 5 \\
\hline $1,3,4,6$-Gal & 1 & & 2 & 1 \\
\hline 1,4-GlcAc & 3 & 18 & 8 & 6 \\
\hline 1,3-GalAc & & & 17 & \\
\hline 3,6-GalAc & & & & 15 \\
\hline 1,3,6-GalAc & & 2 & & \\
\hline 1,2,4-GalAc & & & & 13 \\
\hline AGP amount [\%] & 0 & 75 & 3 & 3 \\
\hline
\end{tabular}

and $-12 \%$ if NHDF. Apoptotic processes in NHDF were not affected by St. John's Wort polysaccharides. In Hp1-treated NHDF $-12 \% \pm 10$ of apoptotic cells were detected, NHDF incubated with $\mathrm{Hp} 2$, and $\mathrm{Hp} 3$ exhibited $-8 \% \pm 6$ respective $-8 \% \pm 8$ of apoptotic cells while Hp4 had no influence $(1 \% \pm 24)$.
Collagen synthesis and release as parameter of fibroblast activity was measured indirectly by determination of hydroxyproline amounts with Direct Red 80 in cells and cell culture supernatant. Compared to untreated control fibroblasts the collagen release was significantly stimulated if NHDFs were incubated with each polysaccharide fraction but in 
TABLE 3: Influence of St. John's Wort polysaccharides on cell physiology of keratinocytes (NEHK and HaCaT). Results were normalized to the untreated cells calculated as $0 \%$. Proliferation was determined by BrdU incorporation ELISA. MTT reduction assay was performed to investigate the intracellular enzyme activity. The cytotoxicity was determined by calculating the extracellular LDH activity compared to total $\mathrm{LDH}$ activity according to the manufacturer instructions. Apoptosis was measured by flow cytometry using Annexin V and 7-AAD.

\begin{tabular}{lcccc}
\hline $\begin{array}{l}\text { Polysaccharide } \\
\text { fraction }\end{array}$ & $\begin{array}{c}\text { Proliferation rate } \\
\text { (NHEK) }\end{array}$ & $\begin{array}{c}\text { Intracellular enzyme } \\
\text { activity (NHEK) }\end{array}$ & $\begin{array}{c}\text { Amount of necrotic } \\
\text { cells (NHEK) }\end{array}$ & $\begin{array}{c}\text { Amount of apoptotic } \\
\text { cells (HaCaT) }\end{array}$ \\
\hline Hp1 & $16 \% \pm 8$ & $17 \% \pm 7$ & $0 \%$ & $13 \% \pm 11$ \\
$\mathrm{Hp} 2$ & $16 \% \pm 9$ & $23 \% \pm 7$ & $4 \%$ & $15 \% \pm 10$ \\
$\mathrm{Hp} 3$ & $-17 \% \pm 8$ & $21 \% \pm 10$ & $8 \%$ & $21 \% \pm 9$ \\
$\mathrm{Hp} 4$ & $10 \% \pm 7$ & $13 \% \pm 6$ & $5 \%$ & $6 \% \pm 3$ \\
\hline
\end{tabular}

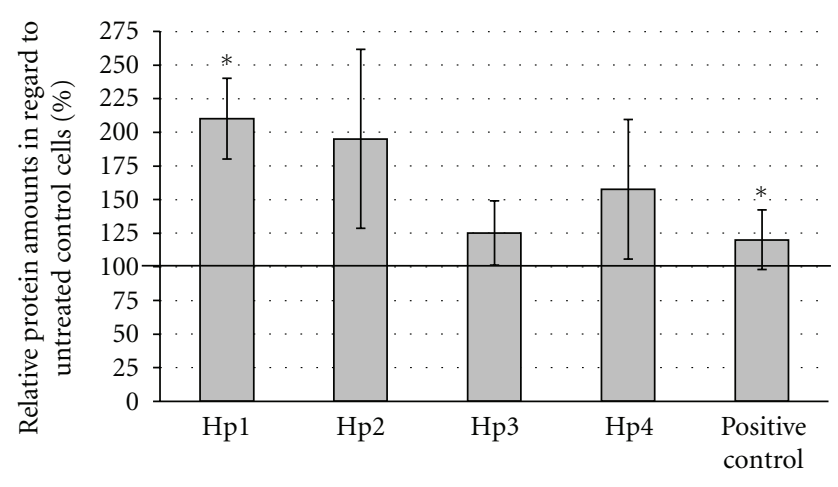

FIGURE 1: Expression of differentiation-specific protein involucrin of NHEK after treatment with $10 \mu \mathrm{g} / \mathrm{mL}$ St. John's Wort polysaccharide fractions for nine days. Protein amounts were determined by semiquantitative dot blot technique. Obtained values with $n=$ 8 were normalized to untreated NHEK (一: untreated NHEK = $100 \%)$. To induce the differentiation, the serum-starved MCDB 153 complete media were supplemented with $13 \mu \mathrm{g} / \mathrm{mL}$ A23187 and $2 \mathrm{mM} \mathrm{Ca}^{2+}$ (positive control).

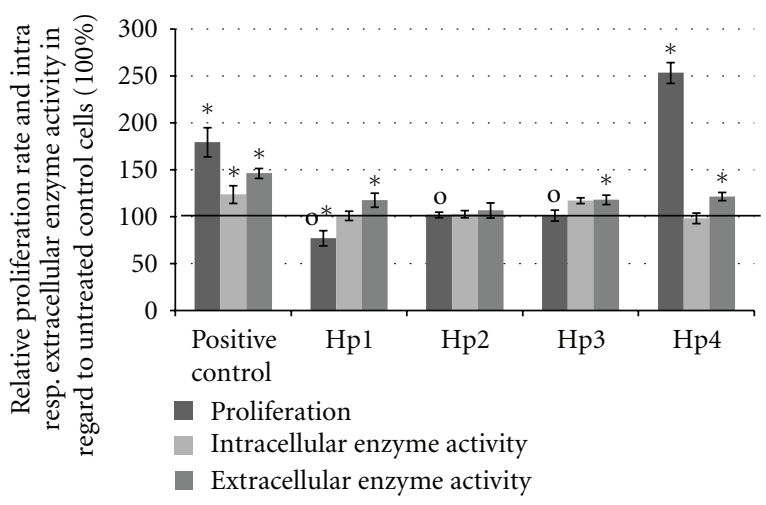

Figure 2: Results of relative proliferation (BrdU incorporation, representative with $n=8$ ) and intracellular (MTT-reduction) and extracellular enzyme activity (WST-1 reduction) of NHDF treated with $10 \mu \mathrm{g} / \mathrm{mL}$ St. John's Wort polysaccharides for $48 \mathrm{~h}$. As positive control, 10\% FCS was used. Values were normalized to untreated cells $(-$ : untreated control $=100 \%) \cdot n=24$. Error bars $=\mathrm{SE}$; ${ }^{*} P<0.05$ compared to untreated cells and o: $P<0.05$ to Hp4.
TABLE 4: Gene expression of NHEK after $6 \mathrm{~h}$ of incubation with $10 \mu \mathrm{g} / \mathrm{mL}$ St. John's Wort polysaccharides in serum-starved media. Results of RT-PCR with TaqMan Assays were normalized to endogenous control 18srRNA and to respective target gene expression of untreated control cells. Regulation was defined as significant with $>2(+)$ and $<0.5(-)$. No change in gene expression is shown as " $\mathrm{o}$ ".

\begin{tabular}{lcccc}
\hline & Involucrin & PLA2 & EGFR & InsR \\
\hline Hp1 & o & - & - & - \\
Hp2 & o & o & o & o \\
Hp3 & o & o & o & o \\
Hp4 & o & + & o & o \\
\hline
\end{tabular}

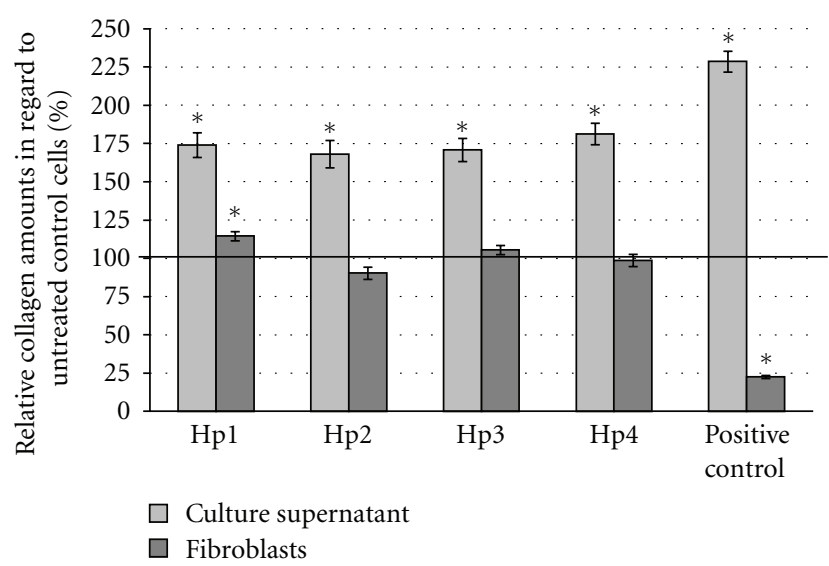

FIGURE 3: Relative amounts of acid soluble collagen of fibroblast culture supernatants and fibroblasts after incubation with $100 \mathrm{mM}$ L-ascorbic acid as positive control and polysaccharide fractions $(10 \mu \mathrm{g} / \mathrm{mL})$. Results were indirectly calculated by determination of hydroxyproline with Direct Red 80. Values shown are normalized to collagen amounts in supernatants and cells of untreated control (一: untreated control $=100 \%)$. ${ }^{*} P<0.05$ compared to untreated cells; $n=4$. Error bars $=\mathrm{SE}$.

less amounts compared to L-ascorbic-acid-treated NHDF (positive control). The amount of remaining intracellular collagen soluble within acetic acid was significantly increased if NHDFs were incubated with $\mathrm{Hp} 1$ but was not altered after incubation with polysaccharide fractions $\mathrm{Hp} 3$ and $\mathrm{Hp} 4$. Polysaccharides of $\mathrm{Hp} 2$ slightly reduced the intracellular acidic collagen amounts (Figure 3 ). 
TABLE 5: Gene expression of NHDF after incubation with $10 \mu \mathrm{g} / \mathrm{mL}$ St. John's Wort polysaccharide fractions in minimal MEM for $6 \mathrm{~h}, 12 \mathrm{~h}$, and $24 \mathrm{~h}$. Results of RT-PCR with TaqMan assays were normalized to endogenous control 18 srRNA and to the respected expression of target genes in untreated control cells. Regulation was defined as significant with $>2(+)$ and $<0.5(-)$. No change in gene expression is shown as " $\mathrm{O}$ ".

\begin{tabular}{lcccc}
\hline Polysaccharide fraction & EGFR & STAT6 & FGF7 & Incubation time \\
\hline Hp1 & - & - & - & \\
Hp2 & o & o & o & $6 \mathrm{~h}$ \\
Hp3 & o & o & o & \\
Hp4 & o & o & o & \\
\hline Hp1 & o & o & o & \\
Hp2 & + & o & o & $12 \mathrm{~h}$ \\
Hp3 & o & o & + & \\
Hp4 & o & o & + & \\
Hp1 & - & o & - & \\
Hp2 & + & o & - & \\
Hp3 & o & o & - & $24 \mathrm{~h}$ \\
Hp4 & o & o & o & \\
\hline
\end{tabular}

3.4. Influence on the Gene Expression of NHDF. NHDF were incubated for $6 \mathrm{~h}, 12 \mathrm{~h}$, and $24 \mathrm{~h}$ with St. John's Wort herb polysaccharide fractions. The epidermal growth factor receptor (EGFR) was not affected by $\mathrm{Hp} 3$ and $\mathrm{Hp} 4$ independent of the incubation time while an increase in gene expression was observed after $12 \mathrm{~h}$ of incubation with Hp2. Hp1 repressed the EGFR gene expression after $6 \mathrm{~h}$ and $24 \mathrm{~h}$ of incubation. The gene expression of the fibroblast growth factor 7 (FGF7) depended on incubation time and used polysaccharide fraction. At $6 \mathrm{~h}$ of incubation the gene expression was reduced by $\mathrm{Hp} 1$ and not changed by the other fractions. If the incubation was prolonged for $6 \mathrm{~h}$ an upregulation occurred if the NHDFs were treated with Hp3 and $\mathrm{Hp} 4$ but after $24 \mathrm{~h}$ this effect inverted. Incubation of $\mathrm{Hp} 2$ resulted in a downregulation of FGF7 gene expression but only after $24 \mathrm{~h}$. The gene expression of the signal transducer and activator of transcription 6 (STAT6) involved in the signaling of IL- 4 was not changed by $\mathrm{Hp} 2, \mathrm{Hp} 3$, and $\mathrm{Hp} 4$ independent of incubation time. During the first $6 \mathrm{~h}$ of incubation Hp1 reduced the STAT6 gene expression but this effect was reverted if the incubation time was prolonged (Table 5).

Gene expression analysis by RT-PCR did not explain the activity of St. John's Wort polysaccharide fractions on NHDF. To get an idea which signal pathways were altered a microarray analysis was carried out. For the microarray analysis polysaccharides of AEC fraction $\mathrm{Hp} 4$ were chosen exemplarily because of their prominent effect on NHDF proliferation. DNA microarray indicated that the expression of 142 of 1308 genes in total changed after incubation for $24 \mathrm{~h}$. But a significant regulation ( $>2$ and $<0.5$ compared to untreated cells) was only found in case of 44 genes (Table 6). These genes were part of cellular processes like inflammation/stress response, transcription, metabolism, cell adhesion/extracellular matrix, and receptor signaling. Mostly an increase in gene expression occurred but the genes related to receptor signaling were predominantly downregulated. This coincides with the results of RTPCR analysis concerning the gene expression of EGFR and KGF. Furthermore, the microarray revealed no influence on the cytokine signaling as it had been shown by RTPCR with STAT6. In more detail prominent changes $(>2)$ in gene expression were observed in case of genes that referred to cellular processes like inflammation (IKBE, FEN1, CXCL1), response to toxins (CMTM7, BGLAP), oxidative stress (SOD2, MUTYH), metabolism (NNMT), extracellular matrix (HSPG2), transcription (HOXD10, EXOSC10), cell motility (ACTG2) and of unknown function (LOC387763, C9ORF16). To a less extent but still significant was the upregulation of genes referring to metabolism and transcription as well as cell adhesion and extracellular matrix as shown in Table 6. Additionally to genes related to receptor signalling (INHBC, CD16, GJB6, ZAP70) the gene expression of IL17A, C-FOS, AFM, CYP3A7, MMP7, and SPARCL1 was significantly decreased. No influence was observed concerning apoptosis, MAPK pathways, TNF signalling, mitochondriaassociated metabolism, calcium signalling, cytoskeleton and translation-related processes.

\section{Discussion}

The presented results show that polysaccharide fractions denominated as $\mathrm{Hp} 1, \mathrm{Hp} 2, \mathrm{Hp} 3$, and $\mathrm{Hp} 4$ differ in acidity, monosaccharide composition, monosaccharide linkage, and their influence on human skin cells.

The polysaccharides belong to water-soluble hemicelluloses, nonswelling pectin, and arabinogalactan proteins (AGPs). In detail the most obvious difference was seen in fraction $\mathrm{Hp} 1$ that was composed of a high amount of glucose. Since the test with Lugol solution that only reacts with helical linked $\alpha$-D-glucose, was negative, the glucose must be part of a $\beta$-D-glucan [28]. In regard to $1: 1$ ratio and linkage of galactose and arabinose a coexistence of an arabinogalactan is likely a result of the limited separation according to the polysaccharide acidity. For the same reason the acidic polysaccharide fractions $\mathrm{Hp} 2, \mathrm{Hp} 3$, and $\mathrm{Hp} 4$ would contain more than one polysaccharide. According to the positive reaction with the Yarif reagent, linkage of arabinose and galactose residues and their proportion pointed to the occurrence of arabinogalactan proteins (AGPs). Furthermore the ratio and linkage of arabinose, rhamnose, galactose, and galacturonic acid as well as the esterification of galacturonic acid indicates the presence of pectic structures. The increasing amounts of galacturonic acid and the different linkage types point to structural differences $[29,30]$. To confirm these data the fractions must be purified and structurally characterized by NMR within future investigations.

Nevertheless the cell-based investigations showed that the polysaccharide fractions affect the skin cells corresponding to their composition and linkage of monosaccharide residues. Obvious was that polysaccharides of fraction $\mathrm{Hp} 1$ had the most efficient activity on NHEK differentiation and collagen synthesis of NHDF compared to the other polysaccharide fractions. According to previous investigations it is 
TABLE 6: Summary of genes with significantly changed expression $(>1.7,<0.5)$ from 1308 genes in total within gene expression analysis using topic-defined PIQOR skin microarray (Miltenyi Biotech, Cologne, Germany) from NHDF after treatment with polysaccharides of $\mathrm{Hp} 4(10 \mu \mathrm{g} / \mathrm{mL})$ compared to an untreated control (=1) for $24 \mathrm{~h}$.

\begin{tabular}{|c|c|c|}
\hline Gene & $\begin{array}{l}\text { Description and function } \\
\text { according to NCBI gene database }\end{array}$ & $\begin{array}{l}\text { Relative regulation } \\
\qquad(\mathrm{SD} \%)\end{array}$ \\
\hline \multicolumn{3}{|l|}{ Miscellaneous } \\
\hline LOC387763 & LOC387763 protein (unknown) & $2.70 / 9 \%$ \\
\hline C9ORF16 & C9ORF16 (unknown) & $2.37 / 21 \%$ \\
\hline ACTG2 & Gamma-2-actin (cell motility) & $2.01 / 29 \%$ \\
\hline GJB6 & Connexin 30 (hyperproliferation) & $0.48 / 32 \%$ \\
\hline \multicolumn{3}{|c|}{ Cell adhesion and extracellular matrix } \\
\hline HSPG2 & Perlecan & $3.05 / 33 \%$ \\
\hline L1CAM & L1 cell adhesion molecule & $1.93 / 13 \%$ \\
\hline FGF11 & Fibroblast growth factor 11 & $1.93 / 13 \%$ \\
\hline PTK7 & Protein-tyrosine kinase 7 & $1.78 / 19 \%$ \\
\hline FAT & Cadherin-related tumor suppressor & $1.73 / 13 \%$ \\
\hline SPARCL1 & SPARC-like protein 1 & $0.48 / 22 \%$ \\
\hline MMP7 & Matrilysin & $0.42 / 14 \%$ \\
\hline \multicolumn{3}{|l|}{ Metabolism } \\
\hline NNMT & Nicotinamide N-methyltransferase & $2.83 / 17 \%$ \\
\hline CA12_2 & Carbonic anhydrase XII & $1.98 / 11 \%$ \\
\hline SLC20A1 & $\begin{array}{l}\text { Member of solute carrier family } 20 \text { (phosphate } \\
\text { transporter) }\end{array}$ & $1.89 / 10 \%$ \\
\hline $\mathrm{MDH} 1$ & Cytoplasmic malate dehydrogenase & $1.84 / 21 \%$ \\
\hline CFTR & cAMP-dependent chloride channel & $1.80 / 4 \%$ \\
\hline GLUT1 & $\begin{array}{l}\text { Solute carrier family } 2 \text { member } 1 \text { (facilitated } \\
\text { glucose transporter) }\end{array}$ & $1.78 / 29 \%$ \\
\hline PEG1-MEST & $\begin{array}{l}\text { Mesoderm-specific transcript homolog } \\
\text { (mouse) }\end{array}$ & $1.71 / 17 \%$ \\
\hline CYP3A7 & Cytochrome P450 3A7 & $0.47 / 23 \%$ \\
\hline AFM & Afamin ( $\alpha$-albumin $)$ & $0.33 / 15 \%$ \\
\hline \multicolumn{3}{|c|}{ Receptor signaling } \\
\hline NRP1 & Neuropilin-1 (CD304 Antigen) & $1.79 / 26 \%$ \\
\hline INHBC & Inhibin $\beta C$ & $0.46 / 19 \%$ \\
\hline CD16 & IGG FC receptor III-2 & $0.43 / 21 \%$ \\
\hline ZAP70 & $\begin{array}{l}\text { Zeta-chain (TCR) associated protein kinase } \\
70 \mathrm{kDa}\end{array}$ & $0.41 / 24 \%$ \\
\hline \multicolumn{3}{|l|}{ Transcription } \\
\hline EXOSC10 & Exosome component 10 & $2.96 / 37 \%$ \\
\hline HOXD10 & Homeobox D10 & $2.04 / 20 \%$ \\
\hline SRRM2 & $\begin{array}{l}\text { Serine/arginine-rich splicing factor-related } \\
\text { nuclear matrix protein of } 300 \mathrm{kDa}\end{array}$ & $1.92 / 33 \%$ \\
\hline MAZ & $\begin{array}{l}\text { MYC-associated zinc finger protein } \\
\text { (purine-binding transcription factor) }\end{array}$ & $1.91 / 17 \%$ \\
\hline ANKRD11 & Ankyrin repeat domain 11 & $1.81 / 23 \%$ \\
\hline MRPL28 & Mitochondrial ribosomal protein L28 & $1.74 / 15 \%$ \\
\hline C-FOS & G0/G1 switch regulatory protein 7 & $0.21 / 1 \%$ \\
\hline
\end{tabular}


TABle 6: Continued.

\begin{tabular}{|c|c|c|}
\hline Gene & $\begin{array}{l}\text { Description and function } \\
\text { according to NCBI gene database }\end{array}$ & $\begin{array}{l}\text { Relative regulation } \\
\qquad(\mathrm{SD} \%)\end{array}$ \\
\hline \multicolumn{3}{|c|}{ Inflammation, stress, and DNA repair } \\
\hline SOD2 & Mitochondrial superoxide dismutase 2 & $4.78 / 22 \%$ \\
\hline CMTM7 & $\begin{array}{l}\text { CKLF-like MARVEL transmembrane } \\
\text { domain-containing protein } 7\end{array}$ & $3.86 / 38 \%$ \\
\hline CXCL1 & Chemokine (C-X-C motif) ligand 1 & $3.33 / 18 \%$ \\
\hline IKBE & $\begin{array}{l}\text { Nuclear factor of kappa light polypeptide gene } \\
\text { enhancer in B-cells inhibitor, epsilon }\end{array}$ & $3.18 / 38 \%$ \\
\hline FEN1 & Flap structure-specific endonuclease 1 & $2.34 / 11 \%$ \\
\hline BGLAP & Bone gamma-carboxyglutamate (gla) protein & $2.07 / 10 \%$ \\
\hline MUTYH & A/G-specific adenine DNA glycosylase & $2.05 / 20 \%$ \\
\hline BTF2P44 & Basic transcription factor $244 \mathrm{kDa}$ subunit & $1.99 / 18 \%$ \\
\hline IKBA & $\begin{array}{l}\text { Nuclear factor of kappa light polypeptide gene } \\
\text { enhancer in B-cells inhibitor, alpha }\end{array}$ & $1.89 / 5 \%$ \\
\hline SERPIN 1 & Serine proteinase inhibitor & $1.83 / 6 \%$ \\
\hline $\mathrm{XBP} 1$ & $\mathrm{X}$-box binding protein 1 & $1.73 / 12 \%$ \\
\hline HSP90B1 & Endoplasmin (heat shock protein $90 \mathrm{~b} 1$ ) & $1.73 / 21 \%$ \\
\hline POLH & Polymerase eta (DNA directed) & $1.70 / 20 \%$ \\
\hline IL17A & Interleukin 17 & $0.45 / 20 \%$ \\
\hline
\end{tabular}

SD: standard deviations from $n=4$ replicates of three biologic repeats.

more likely that the $\beta$-D-glucan is responsible for this effect than the arabinogalactan. Arabinogalactans as well as AGPs have mostly shown to influence the proliferation of different cell types $[7,16,30-32]$ while a similar $\beta$-D-glucan has proven to induce the differentiation of NHEK differentiation. We previously observed this effect in a study about Reed mace fruit polysaccharides [25]. Gene expression studies with keratinocytes and fibroblasts pointed to an influence of $\mathrm{Hp} 1$ on differentiation and proliferation processes by downregulation of genes for growth factors (FGF7), growth factor receptors (EGFRs), and insulin receptor (InsR), which are involved in promotion of proliferation and migration [13]. Especially a decreased EGFR signaling promotes epidermal differentiation [33]. Interestingly the differentiation was not influenced via PLA2 known to regulate the differentiation of keratinocytes [14]. Polysaccharide fractions Hp2, Hp3, and $\mathrm{Hp} 4$ were composed of AGP and pectic structures of different composition and linkage. AGPs as well as pectins are known to be biologically active in regard to their specific structure $[30,34]$. The data of the present study does not allow to allocate the biologic activities neither to a specific AGP nor to a distinct pectic structure. However, it appeared that minor differences concerning linkage and amounts of monosaccharides are responsible for the different activity of these three polysaccharide fractions. Since differences in monosaccharide linkage will alter the structure of the whole polymer the polysaccharides of $\mathrm{Hp} 4$ differed from the polysaccharides of fractions $\mathrm{Hp} 2$ and $\mathrm{Hp} 3$. Treatment of fibroblasts with these three acidic fractions caused a stimulation of the proliferation rates only in case of fraction Hp4. Additionally, ANOVA analysis revealed that this effect was significant not only to untreated control cells but also to the effect of the other polysaccharide fractions. Gene expression analysis by RT-PCR revealed additional difference in their activity on cellular gene level. The effect of Hp4 polysaccharides on the fibroblast proliferation was not based on an influence on the gene expression of growth factors or their receptors as RT-PCR and microarray analysis revealed. At the investigated time point the predominant upregulation pertained to genes that refer to processes involved in oxidative stress (SOD2), response to toxins (CMTM7), and DNA repair (BGLAP). For that it is possible that the increased proliferation is due to a hyperproliferation as stress response. But the down regulation of connexin 30 (GJB6), a marker for hyperproliferation [35], and C-FOS, the lack of induction of inflammation-specific proteins like hypoxia inducible factor $1 \alpha(\mathrm{HIF} 1 \mathrm{~A})$, catalase (CAT), LPS binding protein (LPB), soluble epoxide hydrolase (EPHX2), chaperons and proinflammatory cytokines that are additionally part of the microarray contradict this hypothesis. Additionally the unaltered activity of reducing or antioxidative enzymes in the cells as determined with MTT test disagrees with a cellular response to oxidative stress.

The upregulation of the cytoplasmic malate dehydrogenase (MDH1) is interesting for its involvement in the carbohydrate metabolism. This and the fact that the other regulated genes are involved in transport mechanisms (CFTR, GLUT1, and AFM), drug metabolism (CYP3A7, PEG1MEST, and NNMT) transcription processes (EXOSC10, HOXD10, SRRM2, ANKRD11, and MAZ) led to the hypothesis that the polysaccharides were internalized and catabolized by the cells and that the influence on the cells 
derives from inside and not outside the cell. According to the significant increase in extracellular enzyme activity the catabolism of polysaccharides may already start outside the cell followed by internalization. An internalization of an arabinogalactan with similar activity on cellular processes on gene level has been shown recently [32]. For that future studies must show if the polysaccharides were internalized or if they were degraded on the cell surface. Anyway the proliferation process is also influenced from outside the cell. The significantly upregulated genes of neuropilin (NRP1) and fibroblast growth factor 11 (FGF11) point to an influence of $\mathrm{Hp} 4$ polysaccharides on the FGF signaling [36]. Moreover, the proliferation process is influenced by other signal pathways as indicated by the regulation of perlecan (HSPG2), matrilysin (MMP7), and SPARC-like protein1 (SPARCL1). Another way to support the cell proliferation is to maintain cell adhesion and migration. So it is not surprising that the L1 adhesion molecule (L1CAM) and the cadherin-related tumor suppressor homolog (FAT) gene expression was affected by $\mathrm{Hp} 4$ polysaccharides. The regulation of gene expression may vary over the incubation time as mostly late signal pathway steps were affected. So shortening of incubation time for gene expression studies will show a different pattern of gene expression shifted towards earlier signaling processes and extracellular proteins [37]. The lacking influence on collagen expression coincides with unchanged intracellular collagen amounts indicating no increased or induced collagen synthesis.

Present results show that polysaccharides of different composition and linkage influence human skin cells in different ways. Gene expression studies support the physiologic data and reveal a foundation for the underlying mechanisms of polysaccharide activity.

\section{Conclusion}

Concluding, the water-soluble polysaccharides isolated and characterized from St. John's Wort herb are similar to already described water-soluble plant polysaccharides. Anyway the high $\beta$-D-glucose content and linkage of neutral AEC fraction $\mathrm{Hp} 1$ are characteristic for St. John's Wort herb and uncommon for already described polysaccharides of dicotyledons. Cell physiological investigations showed that the polysaccharides of $\mathrm{Hp} 1$ differ not only in their structure but also in their biological activity from the other extracted polysaccharides. Furthermore, the results obtained with acidic polysaccharides illustrate that slight structural differences lead to obvious differences in the biologic activity. However, future studies are necessary to determine the effective polysaccharide structure. Nevertheless, the presented data demonstrate that polysaccharides play a role in the effect of St. John's Wort extracts on skin cells.

\section{Acknowledgments}

The authors thank Dr. Lohse, Department of Paediatric Surgery, University of Münster, for support with dermal resectates and Mrs. Possemeyer for technical assistance (Institute for Pharmaceutical Biology and Phytochemistry,
University of Münster). The study was financially supported by Professor Hensel, Institute for Pharmaceutical Biology and Phytochemistry, University of Münster.

\section{References}

[1] V. Butterweck and A. Nahrstedt, "What is known about St John's wort? Phytochemistry and pharmacology," Pharmazie in Unserer Zeit, vol. 32, no. 3, pp. 212-219, 2003.

[2] S. Onoue, Y. Seto, M. Ochi et al., "In vitro photochemical and phototoxicological characterization of major constituents in St. John's Wort (Hypericum perforatum) extracts," Phytochemistry, vol. 72, pp. 1814-1820, 2011.

[3] M. C. Meinke, S. Schanzer, S. F. Haag et al., "In vivo photoprotective and anti-inflammatory effect of hyperforin is associated with high antioxidant activity in vitro and ex vivo," European Journal of Pharmaceutics and Biopharmaceutics, vol. 81, no. 2, pp. 346-350, 2012.

[4] M. Müller, K. Essin, K. Hill et al., "Specific TRPC6 channel activation, a novel approach to stimulate keratinocyte differentiation," The Journal of Biological Chemistry, vol. 283, no. 49, pp. 33942-33954, 2008.

[5] C. M. Schempp, T. Windeck, S. Hezel, and J. C. Simon, “Topical treatment of atopic dermatitis with St. John's wort cream - a randomized, placebo controlled, double blind halfside comparison," Phytomedicine, vol. 10, no. 4, pp. 31-37, 2003.

[6] S. G. von Eggelkraut-Gottanka, S. Abu Abed, W. Müller, and P. C. Schmidt, "Quantitative analysis of the active components and the by-products of eight dry extracts of Hypericum perforatum L. (St John's Wort)," Phytochemical Analysis, vol. 13, no. 3, pp. 170-176, 2002.

[7] C. S. Nergard, T. Matsumoto, M. Inngjerdingen et al., "Structural and immunological studies of a pectin and a pectic arabinogalactan from Vernonia kotschyana Sch. Bip. ex Walp. (Asteraceae)," Carbohydrate Research, vol. 340, no. 1, pp. 115130, 2005.

[8] C. Lengsfeld, F. Titgemeyer, G. Faller, and A. Hensel, "Glycosylated compounds from okra inhibit adhesion of Helicobacter pylori to human gastric mucosa," Journal of Agricultural and Food Chemistry, vol. 52, no. 6, pp. 1495-1503, 2004.

[9] X. Shu, X. Liu, C. Fu, and Q. Liang, "Extraction, characterization and antitumor effect of the polysaccharides from star anise (Illicium verum Hook. f.)," Journal of Medicinal Plant Research, vol. 4, no. 24, pp. 2666-2673, 2010.

[10] G. Biagini, A. Bertani, R. Muzzarelli et al., "Wound management with N-carboxybutyl chitosan," Biomaterials, vol. 12, no. 3, pp. 281-286, 1991.

[11] S. P. Liu, W. G. Dong, D. F. Wu, H. S. Luo, and J. P. $\mathrm{Yu}$, "Protective effect of Angelica sinensis polysaccharide on experimental immunological colon injury in rats," World Journal of Gastroenterology, vol. 9, no. 12, pp. 2786-2790, 2003.

[12] G. Peterszegi, N. Isnard, A. M. Robert, and L. Robert, "Studies on skin aging. Preparation and properties of fucose-rich oligoand polysaccharides. Effect on fibroblast proliferation and survival," Biomedicine and Pharmacotherapy, vol. 57, no. 5-6, pp. 187-194, 2003.

[13] V. Mitev and L. Miteva, "Signal transduction in keratinocytes," Experimental Dermatology, vol. 8, no. 2, pp. 96-108, 1999.

[14] J. Zhou, J. G. Haggerty, and L. M. Milstone, "Growth and differentiation regulate CD44 expression on human keratinocytes," In vitro Cellular and Developmental Biology, vol. 35, no. 4, pp. 228-235, 1999. 
[15] M. B. Yaffe, H. Beegen, and R. L. Eckert, "Biophysical characterization of involucrin reveals a molecule ideally suited to function as an intermolecular cross-bridge of the keratinocyte cornified envelope," The Journal of Biological Chemistry, vol. 267, no. 17, pp. 12233-12238, 1992.

[16] A. M. Deters, K. R. Schröder, and A. Hensel, "Kiwi fruit (Actinidia chinensis L.) polysaccharides exert stimulating effects on cell proliferation via enhanced growth factor receptors, energy production, and collagen synthesis of human keratinocytes, fibroblasts, and skin equivalents," Journal of Cellular Physiology, vol. 202, no. 3, pp. 717-722, 2005.

[17] M. Monsigny, C. Petit, and A. C. Roche, "Colorimetric determination of neutral sugars by a resorcinol sulfuric acid micromethod," Analytical Biochemistry, vol. 175, no. 2, pp. 525-530, 1988.

[18] N. Blumenkrantz and G. Asboe Hansen, "New method for quantitative determination of uronic acids," Analytical Biochemistry, vol. 54, no. 2, pp. 484-489, 1973.

[19] M. M. Bradford, "A rapid and sensitive method for the quantitation of microgram quantities of protein utilizing the principle of protein dye binding," Analytical Biochemistry, vol. 72, no. 1-2, pp. 248-254, 1976.

[20] G. J. Van Holst and A. E. Clarke, "Quantification of arabinogalactan-protein in plant extracts by single radial gel diffusion," Analytical Biochemistry, vol. 148, no. 2, pp. 446$450,1985$.

[21] S. I. Hakomori, "A rapid permethylation of glycolipid, and polysaccharide catalyzed by methylsulfinyl carbanion in dimethyl sulfoxide," Journal of Biochemistry, vol. 55, no. 2, pp. 205-208, 1964.

[22] P. J. Harris, R. J. Henry, A. B. Blakeney, and B. A. Stone, "An improved procedure for the methylation analysis of oligosaccharides and polysaccharides," Carbohydrate Research, vol. 127, no. 1, pp. 59-73, 1984.

[23] R. L. Taylor and H. E. Conrad, "Stoichiometric depolymerization of polyuronides and glycosaminoglycuronans to monosaccharides following reduction of their carbodiimideactivated carboxyl groups," Biochemistry, vol. 11, no. 8, pp. 1383-1388, 1972.

[24] C. R. Noe and J. Freissmuth, "Capillary zone electrophoresis of aldose enantiomers: separation after derivatization with S(-)-1-phenylethylamine," Journal of Chromatography A, vol. 704, no. 2, pp. 503-512, 1995.

[25] K. Gescher and A. M. Deters, "Typha latifolia L. fruit polysaccharides induce the differentiation and stimulate the proliferation of human keratinocytes in vitro," Journal of Ethnopharmacology, vol. 137, pp. 352-358, 2011.

[26] T. Mosmann, "Rapid colorimetric assay for cellular growth and survival: application to proliferation and cytotoxicity assays," Journal of Immunological Methods, vol. 65, no. 1-2, pp. 55-63, 1983.

[27] J. M. Davidson, P. A. LuValle, O. Zoia, D. Quaglino Jr., and M. Giro, "Ascorbate differentially regulates elastin and collagen biosynthesis in vascular smooth muscle cells and skin fibroblasts by pretranslational mechanisms," The Journal of Biological Chemistry, vol. 272, no. 1, pp. 345-352, 1997.

[28] D. Reis, B. Vian, D. Darzens, and J. C. Roland, "Sequential patterns of intramural digestion of galactoxyloglucan in tamarind seedlings," Planta, vol. 170, no. 1, pp. 60-73, 1987.

[29] D. Mohnen, "Pectin structure and biosynthesis," Current Opinion in Plant Biology, vol. 11, no. 3, pp. 266-277, 2008.

[30] B. S. Paulsen and H. Barsett, "Bioactive pectic polysaccharides," Advances in Polymer Science, vol. 186, pp. 69-101, 2005.
[31] G. J. Seifert and K. Roberts, "The biology of arabinogalactan proteins," Annual Review of Plant Biology, vol. 58, pp. 137-161, 2007.

[32] J. Zippel, A. Deters, D. Pappai, and A. Hensel, "A high molecular arabinogalactan from Ribes nigrum L.: influence on cell physiology of human skin fibroblasts and keratinocytes and internalization into cells via endosomal transport," Carbohydrate Research, vol. 344, no. 8, pp. 1001-1008, 2009.

[33] S. Getsios, C. L. Simpson, S. I. Kojima et al., "Desmoglein 1-dependent suppression of EGFR signaling promotes epidermal differentiation and morphogenesis," Journal of Cell Biology, vol. 185, no. 7, pp. 1243-1258, 2009.

[34] B. Westereng, T. E. Michaelsen, A. B. Samuelsen, and S. H. Knutsen, "Effects of extraction conditions on the chemical structure and biological activity of white cabbage pectin," Carbohydrate Polymers, vol. 72, no. 1, pp. 32-42, 2008.

[35] G. Lemaître, V. Sivan, J. Lamartine et al., "Connexin 30, a new marker of hyperproliferative epidermis," British Journal of Dermatology, vol. 155, no. 4, pp. 844-846, 2006.

[36] T. P. Yamaguchi and J. Rossant, "Fibroblast growth factors in mammalian development," Current Opinion in Genetics and Development, vol. 5, no. 4, pp. 485-491, 1995.

[37] A. Balsalobre, F. Damiola, and U. Schibler, "A serum shock induces circadian gene expression in mammalian tissue culture cells," Cell, vol. 93, no. 6, pp. 929-937, 1998. 

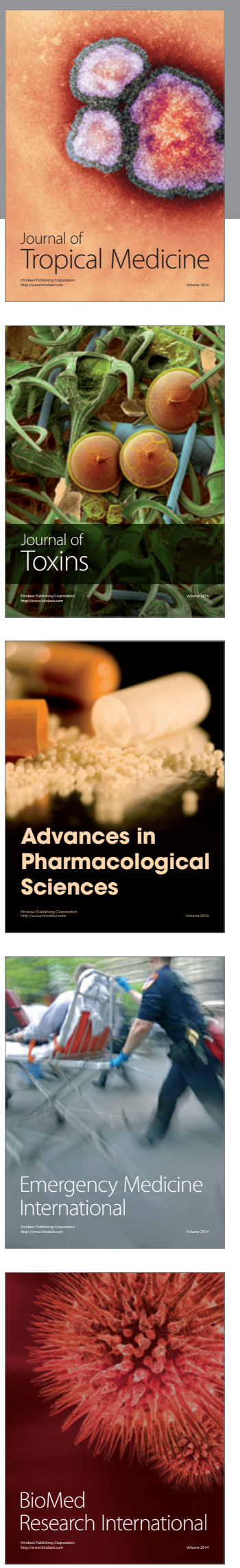
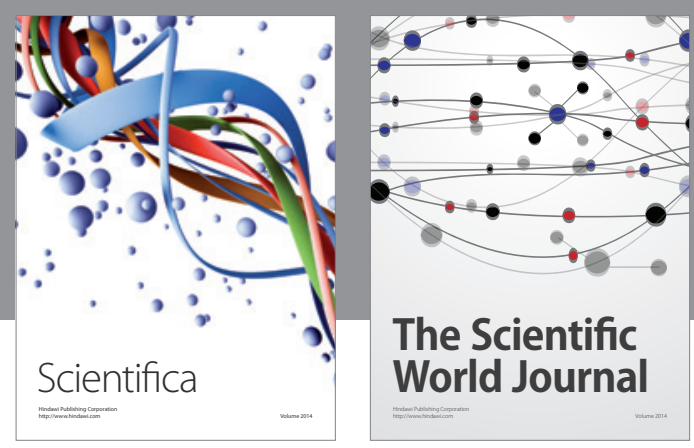

The Scientific World Journal
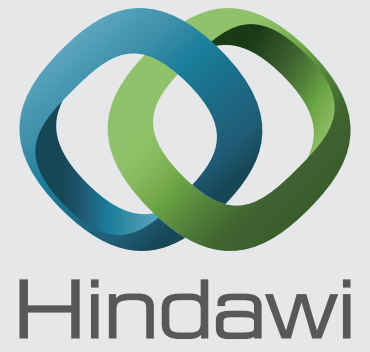

Submit your manuscripts at

http://www.hindawi.com
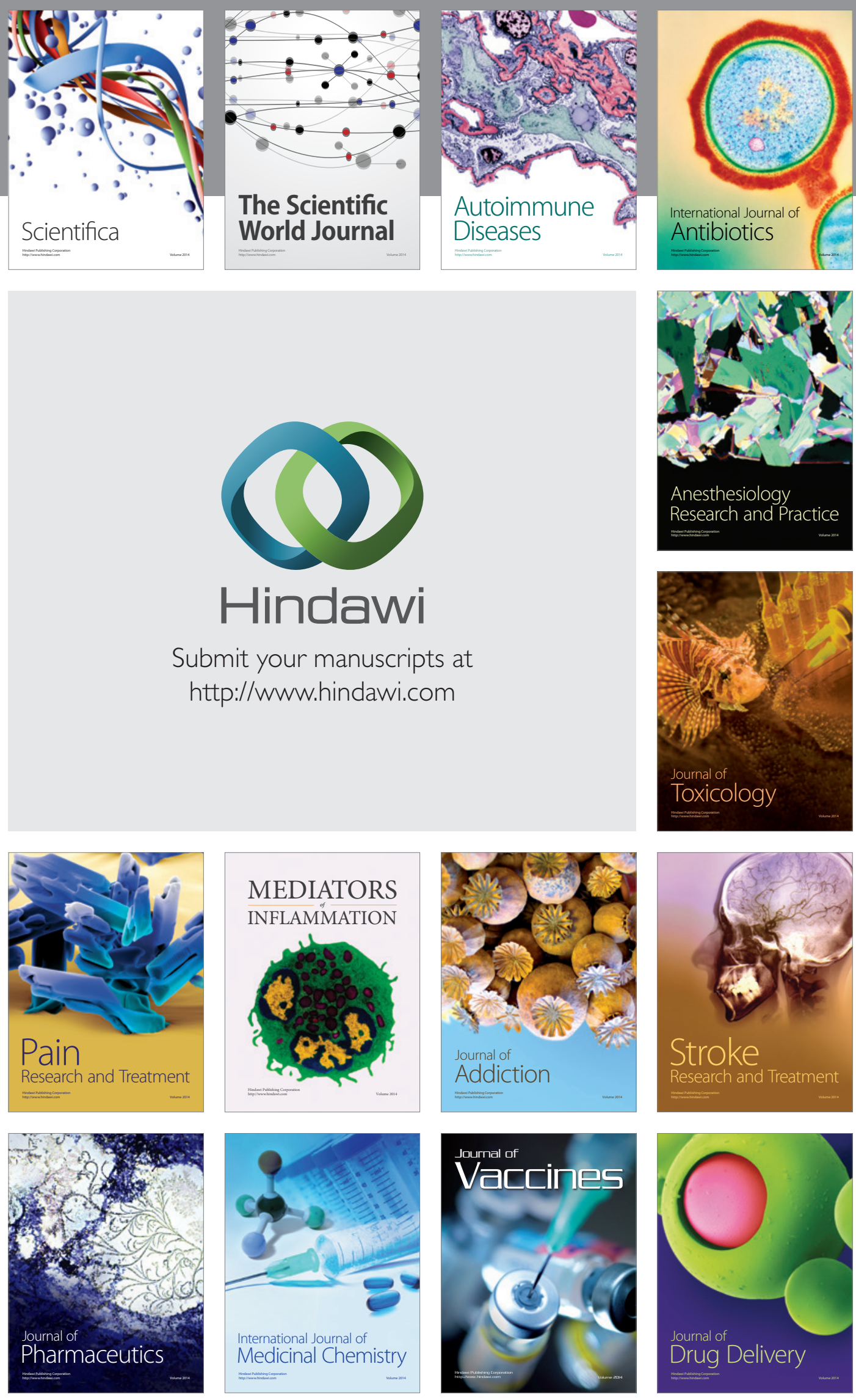